\title{
Immunoglobulin G1 and G2 profile in children with Down syndrome
}

\author{
Supti Prava Saha, Monsura Khan, Ashesh Kumar Chowdhury \\ Department of Immunology, Bangladesh Institute of Research and Rehabilitation in Diabetes, \\ Endocrine and Metabolic Disorder (BIRDEM), Dhaka
}

\begin{abstract}
Background and objectives: It is well known that children with Down syndrome (DS) suffer from frequent infections. There is an association of certain IgG subclass abnormalities with the predisposition to recurrent infection of the respiratory tract. Therefore, the study was conducted to determine the immunoglobulin G1 and G2 (IgG1, IgG2) profile in children with DS.

Material and methods: Forty children between the ages of 6 months to 12 years with DS (47 $\mathrm{XX} / \mathrm{XY},+21)$ attending the Department of Immunology, BIRDEM were enrolled in the study. Age and sex matched 30 healthy normal children with $46 \mathrm{XX} / \mathrm{XY}$ were included as control. Enrolled DS and healthy children were divided into two age groups namely 6 months to 6 years and 7 years to 12 years. Serum IgG1 and IgG2 concentrations were determined by enzyme linked immunosorbent assay (ELISA) method.
\end{abstract}

Results: The mean serum IgG1 concentrations of children with DS in both age groups did not differ significantly from that of normal healthy children. But the IgG2 level was significantly less $(p<0.003$ and $p<0.004)$ in both age groups of children with DS compared to that of control healthy children.

Conclusion: The study has demonstrated that the serum IgG2 level was significantly less in children with DS than that of matched normal healthy control children while there was no deficiency of IgG1.

IMC J Med Sci 2017; 11(1): 1-4

\section{Introduction}

Down syndrome (DS) is one of the most common autosomal disorders. The prevalence of DS in Europe is reported to be 11.2 per 10,000 live births [1]. In USA the prevalence is 8.27 people per 10,000 population [2]. It is widely accepted that DS children suffer from frequent infections than normal children. Infections of the respiratory tract, particularly otitis media, have been identified as one of the most significant health problems in school age children with DS [3]. In previous study, it has been found that $54.9 \%$ children with DS suffer from ear infection and $11 \%$ suffer from upper respiratory tract infection [4]. The lower respiratory tract pathology is the most common cause for acute hospital admission among 1 to 5 years old children with DS [5]. The increased predisposition of infection in individuals with DS is attributed to underlying defects in the immune system which include abnormalities of cell mediated and humoral immune response [6]. In patients with DS, the serum concentration of total IgG may remain within normal range while the IgG2 and IgG4 concentrations are significantly reduced [7]. Also, people with recurrent sinopulmonary infections were found to have a normal serum immunoglobulin level, with selective IgG subclass deficiency [8]. Among the four subclasses of $\mathrm{IgG}$,

Address for Correspondence:

Dr. Supti Prava Saha, Lecturer, Department of Pharmacology, Ibrahim Medical College, 122 Kazi Nazrul Islam Avenue, Shahbag, Dhaka 1000, Bangladesh.Email: pipisu@yahoo.com 
subclass $\mathrm{IgG}_{1}$ and $\mathrm{IgG}_{3}$ are more potent opsonizers than that of $\mathrm{IgG} 2$ and igG4 [9]. IgG1and IgG3 is generally produced in response to protein antigens of bacteria, viruses, vaccines and foods. IgG2 antibodies predominantly act against carbohydrate antigens and are important in protection against polysaccharide encapsulated organisms such as Streptococcus pneumoniae, Haemophilus influenzae and Neisseria meningitides [10]. To date there is no study on immunoglobulin subclass pattern among Bangladeshi children with DS. Therefore, the present study was conducted to determine the IgG1 and IgG2 profile of Bangladeshi children with DS and whether they are different in comparison to normal children of the same age group.

\section{Materials and methods}

The study protocol was approved by the Ethical Review Committee of the Diabetic Association of Bangladesh. Informed consent was obtained from parents of each participant prior to enrollment into the study.

Study population and collection of samples: Children between the ages of 6 months to 12 years having DS (47 XX/XY,+21) attending the Department of Immunology, BIRDEM were enrolled in the study. Age and sex matched healthy normal children with $46 \mathrm{XX} / \mathrm{XY}$ were included as control. The children were divided into two age groups namely, 6 months to 6 years and 7 years to 12 years. About $3 \mathrm{ml}$ of blood was collected aseptically with venipuncture from all participants for estimation of IgG subclasses. Serum was immediately separated and stored in $-80^{\circ} \mathrm{C}$ until analyzed.

Estimation of IgG subclass: The concentration of IgG1 and IgG2 subclasses were determined by commercial sandwich enzyme linked immunosorbent assay (ELISA) kit. The kit was obtained from Elabscience Biotechnology Co, USA. The detection range of IgG1 and $\mathrm{IgG} 2$ was $1.56-100 \mu \mathrm{g} / \mathrm{ml}$.

\section{Result}

A total of 40 children with DS and 30 normal healthy children were included. There were 21 male and 19 female children with DS. There were
30 and 10 DS children in 6 months to 6 years and 7 years to 12 years age groups respectively. There were 15 normal healthy children in each age group. The mean concentration of $\mathrm{IgG} 1$ antibody of children with DS in 6 months to 6 years and 7 years to 12 years were $16.4 \mu \mathrm{g} / \mathrm{ml}$ and $9.9 \mu \mathrm{g} / \mathrm{ml}$ respectively compared to that of $11.5 \mu \mathrm{g} / \mathrm{ml}$ and $6.6 \mu \mathrm{g} / \mathrm{ml}$. The concentration of IgG1 in DS and healthy children was not significantly different. The mean concentration of $\mathrm{IgG}_{2}$ in children with DS was significantly less $(p<0.003$ and $p<0.004)$ than that of normal children in both age groups. Among 6 months to 6 years age group it was $7.4 \pm 5.6 \mu \mathrm{g} / \mathrm{ml}$ in DS versus $15 \pm 9.4 \mu \mathrm{g} / \mathrm{ml}$ in normal children. In 7 years to 12 years age group the mean IgG2 levels were $8.6 \pm 3.2 \mu \mathrm{g} / \mathrm{ml}$ and $14.9 \pm 8.2 \mu \mathrm{g} / \mathrm{ml}$. The detail concentration of $\mathrm{IgG} 1$ and $\mathrm{IgG} 2$ are shown in Table-1.

Table-1: Serum IgG1 and IgG2 levels in children with $D S$ and in normal children

\begin{tabular}{cccccc}
\hline \multirow{2}{*}{ Age } & \multirow{2}{*}{$\begin{array}{c}\text { Study } \\
\text { population }\end{array}$} & \multicolumn{2}{c}{$\mathbf{l g G}_{1}(\mu \mathrm{g} / \mathrm{ml})$} & \multicolumn{2}{c}{$\mathbf{l g G}_{2}(\mu \mathrm{g} / \mathrm{ml})$} \\
\cline { 3 - 6 } & $\mathbf{S D}$ & $\begin{array}{c}\mathbf{P} \\
\text { value }\end{array}$ & $\begin{array}{c}\text { Mean } \pm \\
\text { SD }\end{array}$ & $\begin{array}{c}\mathbf{P} \\
\text { value }\end{array}$ \\
\hline $\begin{array}{c}\text { 6months- } \\
\text { 6years }\end{array}$ & $\mathrm{DS}(\mathrm{n}=30)$ & $16.4 \pm 23.4$ & & $7.4 \pm 5.6$ & \\
& $\mathrm{NH}(\mathrm{n}=15)$ & $11.5 \pm 13.6$ & & $15 \pm 9.4$ & 0.003 \\
7years- & $\mathrm{DS}(\mathrm{n}=10)$ & $9.9 \pm 9.9$ & & $8.6 \pm 3.2$ & \\
12years & $\mathrm{NH}(\mathrm{n}=15)$ & $6.6 \pm 7.1$ & 0.22 & $14.9 \pm 8.2$ & 0.004 \\
\hline
\end{tabular}

Note: Student's independent t test was used to compare between groups.

Mean IgG1 and IgG2 concentrations of DS children was compared with the levels in normal healthy; $D S=$ Down syndrome; $N H=$ Normal healthy.

\section{Discussion}

The present study was conducted to assess IgG1 and IgG2 subclasses patterns in children with DS. Children with DS are more prone to respiratory tract infection $[7,11,12]$. We have demonstrated that in our DS group the serum IgG2 level was significantly less $(p<0.05)$ than that of matched normal control children. However, the IgG1 levels were not different from that of control in both age groups. Therefore, along with the estimation of total IgG, it is important to determine the levels of all IgG subclasses to ascertain the specific abnormalities. The present study has also provided 
the normal range of IgG1 and IgG2 levels of Bangladeshi children between the ages of 6 months to 12 years. No such values for Bangladeshi children are so far known or available. Studies in different country have reported that DS children have reduced or low level of serum IgG2 compared to normal population $[11,12]$. Children with DS with this selective IgG2 deficiency are more susceptible to respiratory tract infection than normal children as because $\operatorname{IgG} 2$ is known to act against bacterial polysaccharide antigens of encapsulated bacteria. In Bangladesh, the prevalence of acute respiratory infection in children is about 5.5 episodes per child year [13]. It is important to determine the incidence and prevalence of respiratory tract infections among IgG2 deficient Bangladeshi DS children as this would help to guide the treatment and prevention of recurrent infections. Previous study has reported that selenium supplementation in children with DS has a significant augmentative effect on the serum concentration of IgG2 and igG4 [14]. Also, intravenous immunoglobulin replacement therapy has been shown to reduce the rate of respiratory tract infections significantly in children with recurrent infections and IgG2 deficiency [15].

The findings of IgG2 deficiency would help to guide proper management of infections of children with DS. The study has further indicated that all IgG subclasses should be assessed to determine the specific therapeutic intervention.

\section{References}

1. Loane M, Morris JK, Addor MC, Arriola L, Budd J, Doray B, et al. Twenty-year trends in the prevalence of Down syndrome and other trisomies in Europe: impact of maternal age and prenatal screening. Eur J Human Genet 2013; 21: 27-33.

2. Presson AP, Partyka G, Jensen KM, Devine OJ, Rasmussen SA, McCabe LL, et al. Current estimate of Down syndrome population prevalence in the United States. $J$ Pediatr 2013; 163(4): 1163-1168.

3. Turner S, Sloper P, Cunningham C, Knussen C. Health problems in children with Down syndrome. Child Care Health Dev 1990; 16: 83-97.
4. Selikowitz M. Health problems and health checks in school-aged children with Down syndrome. J Pediatr Child Health 1992; 28 : 383-386.

5. Hilton JM, Fitzgerald DA, Cooper DM. Respiratory morbidity of hospitalized children with trisomy 21. J Pediatr Child Health 1999; 35: 383-386.

6. Ram G, Chinen J. Infections and immunedeficiency in Down syndrome. Clinical and Experimental Immunology 2011; 164: 9-16. doi:10.1111/j.1365-2249.2011.04335.x.

7. Baptista CB, Charlton J, Mendoca P, Lopes AI, Palha M, Trindade JC. IgG subclasses serum concentrations in a population of children with Down syndrome: comparative study with siblings and general population. Allergologia et Immunopathologia 2002; 30(2): 57-60.

8. Umetsu DT, Ambrosino DM, Quinti I, Siber GR, Geha RS. Recurrent sinopulmonary infection and impaired antibody response to bacterial capsular polysaccharide antigen in children with selective IgG-subclass deficiency. N Engl J Med 1985; 313:1247-1251.

9. Levinson W. Review of medical microbiology and immunology. $13^{\text {th }}$ ed. The McGraw-Hill Companies, Inc. 2014; 510-511.

10. Hjelholt A, Chhristiansen G, SØrensen US, Birkelund S. IgG subclass profiles in normal human sera of antibodies specific to five kinds of microbial antigens. Path Dis 2013; 67: 206-213.

11. Bloemers BLP, van Furth AM, Weijerman ME, Gemke RJBJ, Broers CJM, van den Ende $\mathrm{K}$, et al. Down syndrome: a novel risk factor for respiratory syncytial virus bronchiolitis - a prospective birth-cohort study. Pediatrics 2007; 120: e1076-e81.

12. Hilton JM, Fitzgerald DA, Cooper DM. Respiratory morbidity of hospitalized children with trisomy 21. J Paediatr Child Health 1999; 35: 383-6.

13. Zaman K, Baqui AH, Yunus M, Sack RB, Bateman OM, Chowdhury HR, Black RE. Acute respiratory infections in children: a communitybased longitudinal study in rural Bangladesh. $J$ Trop Pediatr 1997; 43(3): 133-137. 
04 IMC J Med Sci 2017; 11(1): 1-4

Saha SP et al.

14. Anneren G, Magnusson CGM, Nordvall SL. Increase in serum concentrations of $\mathrm{IgG} 2$ and IgG4 by selenium supplementation in children with Down syndrome. Arch Dis Child 1990; 65: 1353-1355.

15. Silk HJ, Ambrosino D, Geha RS. Effect of intravenous gammaglobulin therapy in IgG2 deficient and IgG2 sufficient children with recurrent infections and poor response to immunization with Hemophilus influenzae type b capsular polysaccharide antigen. Ann Allergy 1990; 64(1):21-25. 